\title{
Panel Data Analysis on the Impact of Industry and Macroeconomic Factors on Bank Performance: The Case of Ethiopia
}

\author{
Tesfaye Boru Lelissa (PHD)
}

\begin{abstract}
The study has investigated one of the key research question: how do external factors relate to bank performance? It has set a panel regression model that comprised explanatory variables from the macroeconomic and the banking sector. It has run a regression model based on three dependent performance measures, two of which were related to profit and the rest was a price model. The selected variables have established a relationship with performance in most of the models. The result witnessed the fact that bank performance is determined by factors beyond the management control. These include the macroeconomic situations like economic growth and trade balance. In addition, industry related variables such as the rate of market growth and access to cost saving deposits have impact on performances. Therefore, the study has rejected the hypothesis that external factors (macroeconomic and sector) have no impact on performances.
\end{abstract}

DOI: $10.7176 / \mathrm{EJBM} / 11-10-03$

Publication date: April $30^{\text {th }} 2019$

\section{Introduction}

Ethiopia is rated as one of the fastest growing non-oil exporting economy in the world registering double-digit economic growth rate (averaging at 11\% annually) over the past decade (MOFED, 2017). Much of the growth in economy is attributed to the growth in the agriculture and service sectors (NBE Report, 2016). Nevertheless, alike the situation in Sub-Saharan Africa, the share of the financial sector in the overall economy of Ethiopia is at lower level and can be referred as a shallow financial market (IMF, 2007). Despite the low development of financial market in Ethiopia, literature, however, advocates a strong link between financial sector development and economic growth. Countries with better functioning financial institutions and markets grow faster (Levine, 2005). In Ethiopia as well, considering its notable contribution to economic growth, the financial sector has got government attention for more structural transformation. For instance, reform measures to spur the performance of this sector through liberalization measures were enacted and have been implemented since 1991 (Geda, 2006). As literature suggested, it is expected that the liberalization measures can contribute to enhance deepening of the financial sector and ensuring efficient allocation of resources (McKinnon 1973; Shaw 1973). In addition, the recent economic plan of the country, Growth and Transformation Plan II (GTP II) has set bank growth strategies in an attempt to augment their contribution to the economy. There are also various policy measures intended to regulate and enhance the performance of the banks. Nevertheless, the impact of such policies and factors on the performance of the banks was not adequately analyzed, This study, therefore, bridges this gap and systematically identifies and measures the effects of external factors on the performance of the Ethiopian banking sector using panel data from 2001-2017 taking into account all the commercial banks operating in the country. The study investigates one of the research questions of the study: how different industry and macroeconomic $\mathrm{r}$ factors are related to performances, and then presents the empirical results of these models. The model run therefore explores two key hypotheses: Ho: Industry factors have no impact on bank performances and Ho: Macro economic factors have no impact on bank performances.

\section{Literature Review}

External factors in banking literatures include sector or country wide factors and appear outside the control of the management but have a bearing on performances. There are also studies which attempted to separate the external factors into sector and macroeconomic variable (Ongore ,2011). The former considers industry related factors that commonly affects the individual banks while the later takes into account the general economy wide variables. Some authors, for instance, Chantapong (2005); Olweny and Shipho (2011) provide a focus on the sector variables only as they are commonly shared by banks. Another strand of literature emphasizes the importance of both industry and macroeconomic variables in explaining performance heterogeneities across banks. This literature is based on the structure-conduct-performance (SCP) paradigm and is also applicable to contestable markets, firm-level efficiency, and the roles of ownership and governance in explaining bank performance (Berger, 1995; Berger and Humphrey, 1997; Bikker and Hu, 2002; Goddard et al., 2004). In terms of variables used, one of the sector related factors pointed in the literature is Bank size. This is measured considering the level of the industry market in terms of total deposits ( Civelic \& Al-Alami ,1991) or assets (Smirlock,1985). The variable is considered in the studies as to examine whether large banks are likely to be 
benefited from high level of product and credit diversification. Nevertheless, its relationship with performance has uncertain a prior. This is because on the one hand, an increased diversification level provides an indication on reduced attitude towards risk taking resulting in a lower level of return. On the other edge, bank size awards the benefit of economies of scale for large firms that allow them to bargain more effectively, oversee prices and in the end realize higher prices for their product (Agu, 1992).

Market size and market growth rate are also part of the variables from the banking sector that are theoretically and practically deemed to have a bearing on performances. The market sizes which is mostly represented by the aggregate market deposit of the industry explains the prospect that the entry is much easier in larger than in smaller markets. The relationship with performance therefore is expected to be negative in shallow markets. Nonetheless, there is an evidence on the positive relationship between market size and profitability as banks in large markets take on riskier investments resulting in higher returns (Rhoades \& Rutz ,1982). The market growth rate which is usually computed as the percentage growth in market deposits is another variable used in empirical research to represent industry situation. The measure positively relates with profitability as a rapid market growth offers an opportunity for banks to enlarge profit opportunities (Chirwa, 2001).

The other variable indicative of the industry scenario is the capacity of banks to mobilize cost saving deposits from the market. It is obvious that demand deposit, which is attached with close to zero interest rate, is a cheaper source of fund in the banking system. Studies employing the share of demand deposits from total deposits find that the higher the share of demand deposits in the banks' resource stock, the more profitability is going to be achieved (ibid). Overall, the study considers many of the aforementioned sector specific variables to establish a relationship with performance measures.

With regard to macroeconomic factors, studies consider a well functioning or growing economy as measure by the Gross Domestic Product (GDP) positively impacts Bank performance. This is because the trend in GDP has a strong relationship with the demand for banks assets. For instance, in times of slow economic growth, as the demand for credit in the market falls, that potentially disrupts the intermediary role of banks. In contrast, an economy witnessing a boom or positive growth trajectory, pushes the demand for high credit and creates opportunities for banks. This shows that during boom, the demand for credit is high compared to recession (Athanasoglou et. al., 2005). Likewise, Bourke (1989) presents evidence that economic growth associated with entry barriers to the banking market potentially boost banks' profits.

The other macroeconomic stability indicator, the inflation, is one of the most regularly tested variables as to its relationship with bank performances. Nevertheless, studies are far from conclusive with regard to the link between inflation and performances. Some authors explicating such fact claim that the effect of inflation on banking performance depends on whether inflation is anticipated or unanticipated (Perry, 1992). There are also others that support a positive relationship as a high inflation rate is associated with high loan interest rates resulting in high income. Nevertheless, studies seem to witness that the relationship between inflation level and banks profitability remained to be debatable (ibid), or the direction of the relationship is not clear (Vong and Chan, 2009). The other factor which characterizes the Ethiopian economy and hence determines the trade facilitation role of banks is the trade Balance. The Ethiopian economy stayed in a long time trade deficit with a periodically widening level. Theoretically, literature shows that positive economic growth coupled with a strong export performance positively affects the performance of key economy sectors (Borio et al., 2001). More specifically, banks are beneficiary of a growing export as they can easily acquire forex resources to comfortably serve the needy customers. In the process, they can earn a notable size of income by charging fees for their services.

\section{Methodology}

The study uses firm level (mainly commercial banks) as well as aggregate data of the industry and macro economy. As the objective of the study is to explore the effect of the selected sector and macroeconomic factors on individual banks, a panel data set has been applied. The major data sources are the various annual and quarterly publications and financial accounts of NBE, MOFED and commercial banks. Basically, the coverage is from 2001-2017 and consisting of all commercial banks in Ethiopia.

\section{Variable Definition and priori assumptions}

As clarified on the conceptual framework, the explanatory variables are selected mainly from extant literature with a cautious refinement of those factors which are expected to have significant implications on performances. Therefore, six explanatory variables representing sector and macroeconomic activities are added in the constructed model. The independent variables are related to both profit (RoA and RoE) and price (NIM) measures of performances. This is for the reason that some of the selected variables such as inflation, GDP etc. are expected to have implications not only on the profitability of banks but also on their asset and liability pricing decisions. Therefore, three models consisting of three independent variables are framed to run a regression models on the six explanatory variables. The definition and the expected relationship which are based 
on the literature work are displayed on the below table:

Table1: Definition of External factors

\begin{tabular}{|l|l|l|}
\hline Variables & Definition & $\begin{array}{l}\text { Expected } \\
\text { relationship }\end{array}$ \\
\hline Dependent & & \\
\hline ROA & ability of a bank's management to generate profits from the bank's assets & \\
\hline ROE & the return to shareholders on their equity & \\
\hline NIM & $\begin{array}{l}\text { residual of interest income resulted from efficient decision making of } \\
\text { management }\end{array}$ & \\
\hline Independent & & + \\
\hline MKGD & Annual growth of the banking sector deposit & $+/-$ \\
\hline LGTA & Size of banks- natural log of the total asset of banks & + \\
\hline DDTD & Share of demand deposits from total deposits & + \\
\hline RGDP & Growth in real Gross Domestic Product & $+/-$ \\
\hline INF & Annual rate of inflation & - \\
\hline TRDB & Trade balance as difference between export and import & \\
\hline
\end{tabular}

Source: Author's computation

\section{Model Construction}

Several regression models are introduced so as to examine the impacts of external factors consisting of both sector and macroeconomic variables on performances. As pointed out in the literature review, external factors are defined to consist of factors which are beyond the control of bank management. From the extant literature, it appears obvious that bank performance could be affected not only by bank specific scenarios, but also has influence arising from the situation in the external environment. As discussed above, two sets of hypotheses were built based on the research questions of the study. Therefore, the model constructed should have considerations for both elements of an external factors i.e. sector and macro economic variables. The purpose is to test a relationship between each factor representing sector and macroeconomic scenario with bank performances. Hence, the model can be formulated as shown below:

$$
\operatorname{Per}_{\mathrm{jt}}=\mathrm{f}\left(\mathrm{SS}_{\mathrm{t}}, \mathrm{MS}_{\mathrm{t}}\right)
$$

Where Per $_{j \mathrm{t}}$ represents performance measure/s for bank $\mathrm{j}$ during period $\mathrm{t} ; \mathrm{SS}_{\mathrm{t}}$ are sector specific external determinants at time $\mathrm{t}$ and $\mathrm{MS}_{\mathrm{t}}$ are macroeconomic variables at time $\mathrm{t}$. The general model to be estimated is of the following linear form:

$$
\begin{gathered}
\mathrm{pER}_{\mathrm{jt}}=\beta_{\mathrm{j}}+\sum \beta_{\mathrm{k}} \mathrm{X}_{\mathrm{jt}}^{\mathrm{K}}+\varepsilon_{\mathrm{jt}} \\
\varepsilon_{\mathrm{jt}}=\mathrm{v}_{\mathrm{i}}+\mathrm{u}_{\mathrm{jt}}
\end{gathered}
$$

Where Per ${ }_{\mathrm{jt}}$ is the profitability of bank $\mathrm{j}$ at time $\mathrm{t}$, with $\mathrm{i}=1 \ldots \mathrm{N} ; \mathrm{t}=1 \ldots \mathrm{T}, \beta_{\mathrm{j}}$ is a constant term, $\mathrm{X}_{\mathrm{jt}}$ are $\mathrm{k}$ explanatory variables and $\varepsilon_{j t}$ is the disturbance with $v_{j}$ the unobserved bank-specific effect and $u_{j t}$ the idiosyncratic error. The explanatory variables are grouped as per equation 1 as industry specific and macroeconomic specific determinants. Hence, substitution of equation 1 in to equation 2 yields the following general specification model:

$$
\operatorname{Per}_{j t}=\beta_{\mathrm{j}}+\sum \beta_{\mathrm{k}} \mathrm{X}^{\mathrm{SS}}{ }_{\mathrm{jt}}+\sum \beta_{\mathrm{k}} \mathrm{X}^{\mathrm{MS}}{ }_{\mathrm{jt}}+\varepsilon_{\mathrm{jt}}
$$

Where, the xjt with superscripts SS and MS represent the sector specific and macro-economic specific determinants as stated in equation 1 .

More specifically, the econometric model can be expressed in mathematical form incorporating the identified variables. In order to allow for the inexact relationship among the variables as in the case of most economic time series, variables error term' $\varepsilon i, t_{\mathrm{t}}$ ' is added to form equations.

\section{Model I:}

$\mathrm{RoA}_{\mathrm{tJ}}=\beta 0+\beta 1 \mathrm{MKGD} i, t+\beta 2 \mathrm{LGTA} i, t+\beta 3 \mathrm{DDTD} i, t+\beta 4 \mathrm{RGDP} i, t+\beta 5 \mathrm{INF} i, t+\beta 6 \mathrm{TRDB}+\varepsilon i, t$

Model II:

$\mathrm{RoE}_{\mathrm{tJ}}=\beta 0+\beta 1 \mathrm{MKGD} i, t+\beta 2 \mathrm{LGTA} i, t+\beta 3 \mathrm{DDTD} i, t+\beta 4 \mathrm{RGDP} i, t+\beta 5 \mathrm{INF} i, t+\beta 6 \mathrm{TRDB}+\varepsilon i, t$

Model III

$\mathrm{NIM}_{\mathrm{Jt}}=\beta 0+\beta 1 \mathrm{MKGD} i, t+\beta 2 \mathrm{LGTA} i, t+\beta 3 \mathrm{DDTD} i, t+\beta 4 \mathrm{RGDP} i, t+\beta 5 \mathrm{INF} i, t+\beta 6 \mathrm{TRDB}+\varepsilon i, t$ 
Where, RoA, ROE and NIM correspond to performance measures representing profit and prices, MKGDmarket deposit growth rate, LGTA- natural logarithm of banks total assets, DDTD- share of demand deposit from total deposit, RGDP- real GDP growth rate, INF- annual inflation rate and TRDB- trade balance .

\section{Descriptive Statistics and Trends}

The growth in economy as measured by the commonly used standard, the Gross Domestic product (GDP), has been strong with an average real GDP growth rate closer to double digit during 2001-2017. More specifically, the recent period (last five years) performance has been notable and averaged a double digit growth rate record that placed Ethiopia to be among the fast growing economy of the world. The growth rate in economy in all periods considered, except year 2002, has been positive. The negative growth record during 2002/3 is mainly associated with the cyclical draught that prevails in the system in every ten years interval due to adverse climatic conditions. A recovery in the overall economic performance has been registered, especially since 2004, as measured by real GDP. The growth has not only brought an improvement on the aggregate economic performances, but has also brought in a transformation of the economy towards service dominated (MOFED, 2014). This is a new episode considering the long standing agriculture based economy which remained as a mainstay for large part of the population in the country. The recent Growth and Transformation Plans (GTP I and II) also asserted for more transformation and growth in the economy through boosting the performance of export, industry and agriculture sectors. The banking sector is also one of a policy target which is expected to register a $30 \%$ growth in loan and deposit performances through opening more branches ( $25 \%$ growth) and offering agent banking services ( 1 branch to 50 agent). Furthermore, banks are expected to raise their current paid up capital level to Birr 2 billion and maintain their non performing asset level to 5\% (NBE Circular MFAD/205/15). Such growth trajectories and policy directions obviously will have implication on the strategy of banks to meet their growth motives. Therefore, the implication of economic performances and polices set, therefore, deserve an exploration towards their effect. This remains to be one of the basic objectives of the study as set out in the research question. This part of the study, therefore, mainly considers the impact of economic growth on banks performance. Specific analysis on sector related regulations and policy directions, however, will be observed in the next section of the study through investigating the impact of regulatory variables on performances.

Table 2: Descriptive Statistics of External Factors

\begin{tabular}{|lrrrrrrrrr|}
\hline & $\mathrm{N}$ & \multicolumn{1}{c}{ Minimum } & \multicolumn{1}{c}{ Maximum } & \multicolumn{1}{c}{ Mean } & \multicolumn{1}{l}{ Std. Deviation } & \multicolumn{1}{l}{ Skewness } & \multicolumn{2}{c|}{ Kurtosis } \\
\hline ROE & 193 & .00 & 90.82 & 18.9962 & 12.87965 & 1.697 & .175 & 6.461 & .348 \\
\hline ROA & 193 & .00 & 5.25 & 2.2333 & 1.10661 & -.312 & .175 & -.252 & .348 \\
\hline NIM & 193 & .00 & 10.16 & 4.5473 & 1.80649 & .265 & .175 & -.055 & .348 \\
\hline RGDP & 193 & -2.10 & 12.60 & 9.0886 & 3.48685 & -1.888 & .175 & 2.896 & .348 \\
\hline TRDB & 193 & -216648.5 & -7135.00 & -84371.2 & 70757.7 & -.596 & .175 & -1.026 & .348 \\
\hline INFL & 193 & -10.60 & 36.40 & 12.8699 & 11.54748 & .614 & .175 & .003 & .348 \\
\hline MKGD & 193 & 10.27 & 43.98 & 23.4189 & 8.49858 & .684 & .175 & .520 & .348 \\
\hline LGTA & 193 & 4.33 & 12.53 & 8.0527 & 1.45669 & .434 & .175 & .423 & .348 \\
\hline DDTD & 193 & 10.01 & 70.20 & 32.0270 & 12.20197 & .787 & .175 & .185 & .348 \\
\hline ValiN & & & & & & & &
\end{tabular}

Valid N (listwise) 193

\section{Source : Author's Computation}

The other variable, net trade (TRDB), has been negative throughout all the periods considered in the study as the country buys more goods and services from abroad than it sells resulting in net trade deficit. Trend wise, the trade balance also deteriorated in relation to high import growth which is again due to the country's high demand in investment goods to develop the economy. A further split of the trade deficit shows that foreign exchange earnings from export of goods and services have exhibited a growth magnitude but dominantly at a decreasing rate (Chart 1). This is mainly due to inherent structural problems in tradable goods as well as price and demand volatility and stiff competition in the international market (NBE report, 2016). However, the recent period record shows a decreasing trend owing to the above stated factors and contributing for the wider merchandise trade deficit. In contrast, merchandise import has been progressively growing consuming foreign currency level beyond that earned by export of merchandises. This in short has put the country in general and the commercial banks in particular in a foreign currency liquidity stress situation. Such scenario could explicate the fact for the prevalence of a stiff competition among banks to attract more exporters so that they could advance their performances through offering foreign currencies to the needy importers. Nevertheless, the exchange rate in Ethiopia is managed and banks are expected to get earnings from foreign exchange transaction through setting the difference between buying and selling exchange rate not exceeding $2 \%$. The banks, however, have the discretion to set the fees and commissions collected through offering international banking services. This section of the study, therefore, aims at examining the effect of the availability of foreign exchange that mainly originated from export earnings on their performances. It has used the trade deficit level to examine the dual effect of 
export and import activities on banking performances. However, impacts from policy framework such as managed exchange rate will be assessed in the next section of the study.

Figure 1.: Trends in Export, Import and Trade Deficit from 2001-2017

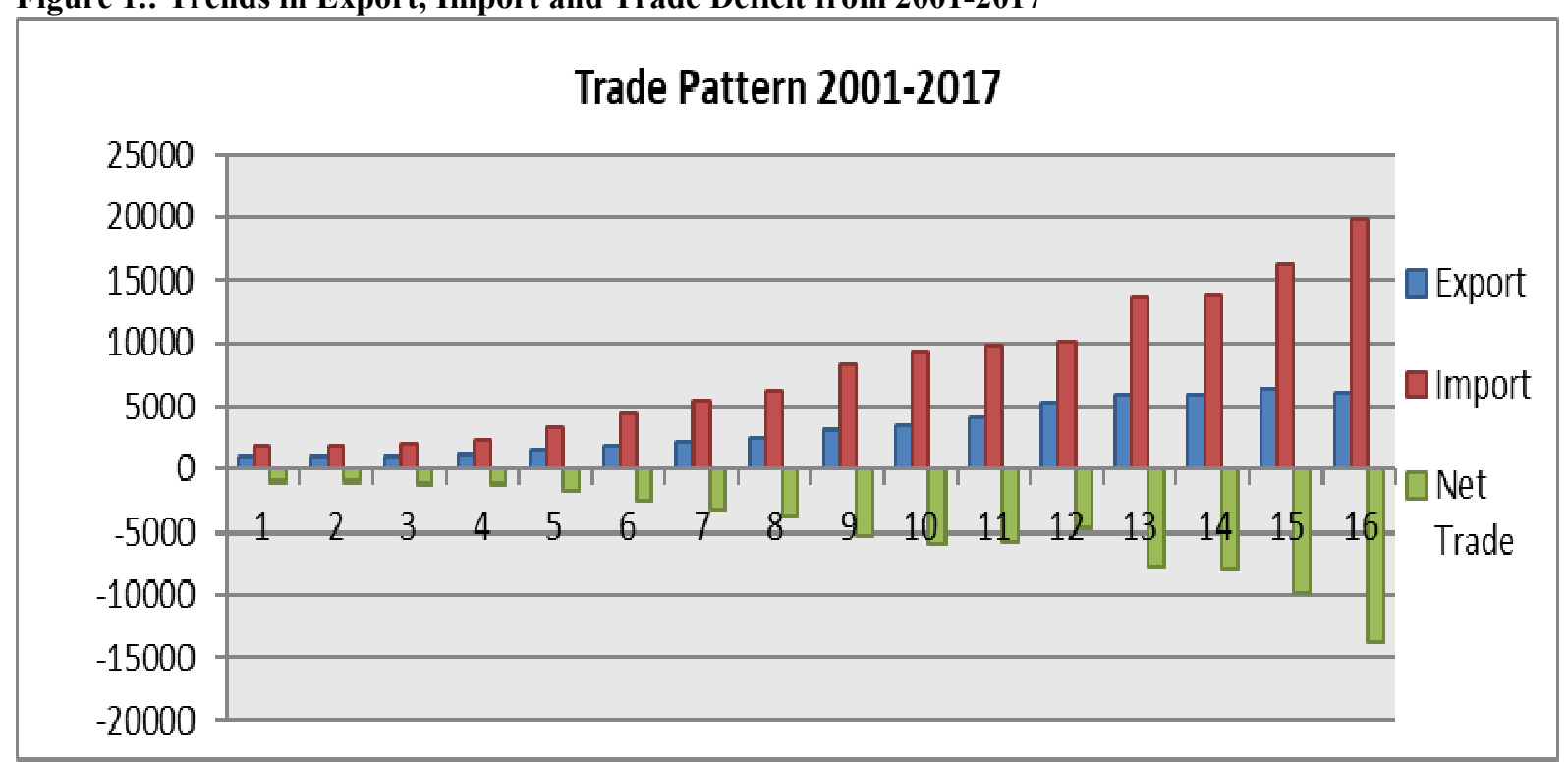

\section{Source: Author's Computation}

With regard to Inflation, the past year records show that inflation in Ethiopia has been low. However, the recent period records show that the economy has been operating with high inflationary spiral. It has been steadily soaring and creeping up in the recent period despite good harvest of agricultural produces. The general inflation reached $36.4 \%$ in year 2009/10, but has recently been reduced to single digit level in 2014 and 2015 owning to various policy measures and commitment of the government to contain inflation at single digit level (GTP II, 2015). As pointed in the literature review, the impact of inflation on bank performance has been widely considered in studies but its direction of impact has no conclusive a priori. However, there is a consensus among scholars regarding the impact of high inflation on economic performance through discouraging savings and hence investment. In the Ethiopian context, due to lifted inflation, the real saving rate has been negative in all periods considered. Similarly, the lending rate remained positive in most years of the period, but has been negative during the years with hyper inflation records. Therefore, with such framework, inflation remained to be an important factor to be considered as to its impact on bank performances.

At the backdrop of such macroeconomic profile, however, the banking industry, as measured by deposit market growth rate (MKGD), has been expanding well with average growth rate of $23 \%$ during 2001-2017. The variation in growth rate, however, is significant with a range of $33 \%$ and the industry growth in some periods reaches to the maximum of $43 \%$. Therefore, the banking industry seems successful in the resource mobilization front that contributed well to the sector balance sheet expansions and earning performances. This has been well observed in the other sector related variable, banks size (LGTA), which has maintained around Birr 437 billion asset reserve with a similar growth trend with the growth of the industry deposit.

The other variable in the study, the share of demand deposits from total deposit stock, measures the impact of availability of cost free deposits on performances. The average share of demand deposits on total deposit is $32 \%$ with a noted significant variation. The high share demand deposit is expected to contribute to good performances through reducing the interest paid on deposit mobilized from the market.

\section{Pearson Correlations}

The correlation between explanatory variables in most of the variables is not large to pose multicollianrity problems. Nevertheless, the relationship among most explanatory variables is significant to provide confidence that there is a genuine relationship between the variables in the model. For instance, the relationship between TRDB and all other explanatory variables has been negative and significant. The widened trade deficit impacts the growth in the market, bank size and the possibility of mobilizing cost saving deposits. Furthermore, the impact of negative trade deficit also extends towards macroeconomic variables through negatively economic growth, the consumer price index. This follows from the diverse effect of a trade deficit on the capacity of the industry to raise resources from foreign exchange earnings, constraining investment endeavor as a result of shortage in foreign currencies, exposing the economy to imported inflation etc. among others. On the other front, except with trade deficit, the real GDP growth rate has established a positive correlation which is a result of a good performance economy on the sector growth, on cost effective resource mobilization and stable prices. 
Similarly, all sector specific variables are positively and significantly related to each other signifying among others a well growing banking sector. This causes a cost effective resource mobilization and remains suitable for the growth in the size of banks in the system.

\begin{tabular}{|c|c|c|c|c|c|c|c|c|}
\hline & ROE & ROA & NIM & RGDP & TRDB & MKRD & LGTA & DDTD \\
\hline ROE & 1.0000 & & & & & & & \\
\hline ROA & 0.6517 & 1.0000 & & & & & & \\
\hline NIM & -0.1432 & .0229 & 1.0000 & & & & & \\
\hline RGDP & 0.2571 & .3772 & 0.0904 & 1.0000 & & & & \\
\hline TRDB & -0.1574 & -0.3515 & -0.3163 & -0.3302 & 1.0000 & & & \\
\hline MKRD & 0.2150 & 0.4046 & 0.1774 & 0.5279 & -0.5081 & 1.0000 & & \\
\hline LGTA & 0.2389 & 0.1566 & 0.2212 & 0.2520 & 0.2426 & -0.0485 & 1.0000 & \\
\hline DDTD & 0.2731 & 0.0228 & 0.1091 & 0.1631 & -0.0932 & 0.2093 & 0.0251 & 1.0000 \\
\hline
\end{tabular}

Source: Author Computation

\section{Model pre-test}

The Fisher Type unit root test which appears more pertinent considering the unbalanced data stock on panel is used to test stationerity. Therefore, the basic hypothesis Ho: All pane 1(longitudinal)s contain unit roots that are tested and the result witnessed that all variables are stationery at zero ADF. In addition, the normality test through kurtosis and skewness witnesses the normality of the data. As shown in the table below, both the F-test and the LM test result reject the null hypothesis (Table 4). Hence, the fixed and random effect models appear better than pooled OLS. The estimation results are presented based on the result of the Hausman test as shown in the regression table below.

\section{Empirical Results}

The impact of the economic growth rate (RGDP) on bank performance is positive and significant in the profit models. The result is in line with the a priori restrictions justifying the significant impact of economic growth on the profitability of banks. The result will not be a surprise considering the effect of a high growing economy in enhancing the credit demand and saving propensity of bank customers from the mounting per capital income. Therefore, banks enjoy a comfortable platform that enhances their earning from the intermediation business. In addition, a well functioning economy poses less threat of credit default that potentially reduces the exposure of the Banks profit to problem asset related expenses. Nevertheless, unexpectedly, the impact of RGDP on the price measure (NIM) is negative. The relationship, however, poses that in times of good economic performances banks' price on credit and/or resource mobilization is negatively affected. As per the conventional demand theory, this is due to the fact that a high demand for credit lowers the lending price as a result of abundant credit offering in the system. Nevertheless, banks could not have discretion to similarly respond to excess supply of resources (deposits) in the market as the minimum interest rate on saving and fixed time deposits is already affixed by the regulatory organ. 
Table 4: Regression Results for External Factors

\begin{tabular}{|c|c|c|c|}
\hline & Model 1 & Model 2 & Model 3 \\
\hline & RoA & RoE & NIM \\
\hline \multirow[t]{2}{*}{ RGDP } & .0743999 & .5339852 & -.0153796 \\
\hline & $(0.0010)^{*}$ & $(0.0230)^{*}$ & $(0.7120)$ \\
\hline \multirow[t]{2}{*}{ TRDB } & -4.61023 & -.0000285 & -.7 .3600 \\
\hline & $(0.0000)^{*}$ & $(0.0470) *$ & $(0.0100) *$ \\
\hline \multirow[t]{2}{*}{ INF } & .0061726 & .0399411 & .0007228 \\
\hline & $(0.3190)$ & $(0.5350)$ & $(0.9510)$ \\
\hline \multirow[t]{2}{*}{ MKGD } & .0317477 & .2771313 & -.0002193 \\
\hline & $(0.0030)^{*}$ & $(0.0130)^{*}$ & $(0.0991)$ \\
\hline \multirow[t]{2}{*}{ LGTA } & -.1153088 & 2.945425 & -.0000826 \\
\hline & $(0.1170)$ & $(0.0180)^{*}$ & $(0.6940)$ \\
\hline \multirow[t]{2}{*}{ DDTD } & .0110495 & .1558825 & .0105274 \\
\hline & $(0.1600)$ & $(0.1420)$ & $(0.3880)$ \\
\hline \multirow[t]{2}{*}{ CONS } & 1.514032 & -13.99182 & 4.176232 \\
\hline & $(0.0090)^{*}$ & $(0.1130)$ & $(0.0000) *$ \\
\hline Adjusted R2 & $36.6 \%$ & $34.4 \%$ & $31.0 \%$ \\
\hline \multirow{2}{*}{ Walid Chi2 } & 86.6 & 152.72 & 16.37 \\
\hline & $(0.0000)^{*}$ & $(0.0000)^{*}$ & $(0.119)^{*}$ \\
\hline \multirow[t]{2}{*}{$\mathrm{F}(6,169)$} & & 14.53 & \\
\hline & & $(0.0000)^{*}$ & \\
\hline \multirow[t]{2}{*}{ F-test } & 4.25 & 10.3 & 3.03 \\
\hline & $(0.0000)^{*}$ & $(0.0000)^{*}$ & $(0.0100)^{*}$ \\
\hline \multirow[t]{2}{*}{ LM test } & 27.6 & 101.3 & 7.9 \\
\hline & $(0.0000)^{*}$ & $(0.0000)^{*}$ & $(0.0050) *$ \\
\hline \multirow[t]{2}{*}{ Hausman Chi2 } & 1.96 & 15.74 & 2.33 \\
\hline & $(0.85430)$ & $(0.0076)^{*}$ & $(0.3252)$ \\
\hline rho(fraction of variance due to $\left.u \_i\right)$ & .16203462 & .64914329 & .04567747 \\
\hline
\end{tabular}

\section{Source: Author's Computation (STATA 12)}

The impact of trade deficit on performances resulted in a consistent result among all models considered. In other words, the result shows that being a net importing country has a negative and significant impact on both profitability (RoA and RoE) and price (NIM) measures. The result, therefore, points that the widening trade deficit should be one of the determinant macroeconomic variables to be considered by the government in its policy framework to improve bank performances. Most importantly, economies with enormous trade deficit that derived from the double edge impact of a rise on import demand and deteriorating export performances could potentially impact their banking performances. The sluggish growth in earnings from export affects the capacity to mobilize both local and foreign currency denominated resources from the market.

The effect of such trend remained significant because of its strong effect on both channels of the banks income sources. On the one side, less export earning affects the intermediation business through limiting the opportunity to raise abundant local deposits. On the other front, it affects the earning from international banking activities by channeling lower amount of foreign currency to the banking system. Most importantly, the limited export earning leads to unfair competition and behavior to reign in the system. This has been one of the issues attracting regulatory involvement and that attempted to address the problem through instructing banks to entertain customers request for foreign currencies on first come first serve basis(with the exclusion of priority sectors like manufacturing). The intent of the involvement is to reduce the rent seeking behavior and unfair competition in the system. Similarly, unparallel rise in import activities with export also creates a foreign currency liquidity shortage that affects the swiftness of trade and the timely collection of earnings. In such scenario, importers are obliged to remain in the banks' waiting list to demand for foreign currency allocation. This obviously affects the trade facilitation role of banks as well as their plan for timely disbursement of credits. Therefore, the intermediation role is affected to timely generate income from loan disbursement to the import sector.

Another variable entertaining consistency of result across the models is inflation. The study finds that the annual rate of inflation has established a positive relationship with performances. The result suggests that better bank performances are related in times of high inflation. This remains to be unexpected result considering from theoretical and practical scenarios. From theoretical view point, a growing inflation rate is expected to affect performance of the economy making consumption expensive. This affects the saving rate in the economy and, hence, lowers the investment fund. This directly affects the growth in the economy and the financial system. From practical perspective, the Ethiopian banking system does not seem to feel the pressure from inflation due to 
its liberty to set the lending prices following the change in deposit rate that for long period ensures a constant spread. In addition, the variation in both lending and deposit rates was not frequent to disrupt banks' price setting mechanisms leading to almost a fixed rate regime in both asset and liability pricing. Therefore, the expected relationship should either be negative or neutral in line with the theoretical and practical arguments, respectively. The positive relationship, therefore, remains unexpected. Nevertheless, previous literature on the effect of inflation displayed similar confusing result. Some scholars say that the relationship between inflation and bank performance is debatable (Athanasoglo, 2005). The direction of relationship is unclear (Vong and Chan 2009) or the effect depends on whether inflation is anticipated or unanticipated (Perry 1992). Therefore, we opted to present the result of the study to get expert opinion of bank managers and regulatory staff. Their opinions support the fact that the effect of inflation on performance should look beyond its impact on asset and liability prices. The effect, however, provides much sense if one considers the impact of inflation on the debt repayment capacity of borrowers. That is, during the time of high inflation, borrowers' ability to meet commitment is higher as they are enjoying a negative real interest rate (lending rate below the inflation rate). Therefore, banks are exposed to a lower risk of default. In addition, the real negative saving rate during inflationary period allows banks to mobilize cheap sources of funds. Therefore, the net gain of banks depends on the magnitude of impact of a negative lending and saving rate. Nevertheless, the study finds that the relationship of inflation with bank performances is not significant.

The impact of market growth rate (MKGD) established a positive and statistically significant relationship with the profitability measures (RoA and RoE). The result is as expected following the argument as an expanding market provides an opportunity to mobilize resources at ease. Therefore, the intermediation business is reinforced as a result of the strength in the supply side. With a parallel growth in the demand side (credit), the intermediation activity of banks will be strong to yield notable profitability performances. Nevertheless, the study finds that the growth in market is negatively associated with the price model (NIM). This remains in line with our argument above in which in times of heated intermediation associated to high demand for credits and excess supply for deposits, the lending interest rate will be in pressure. The price on excess supply in funds, however, remained unaffected to get reduced beyond a level set by the regulator. The cumulative impact drives the net interest margin on the declining trend. On the other front, during excess growth of resources that potentially leads to excess fund holding, there remains a growing competition among banks for credit disbursement whose effect on lending prices remains strong.The relationship established, however, is not statistically significant. On the other front, large size banks are also operating in low risk scenario which is affecting to match their profitability level with their asset holdings.

The variable representing banks size, natural log of total assets (LGTA), has a statistically significant relationship in RoE and statistically insignificant relationship with other models. As set out in a priori assumption, the impact of bank sizes on profitability witnesses uncertain effect on performance. This is due to its mixed impact on performances. On the one hand, bank size suggests increased diversification that exposes banks to operate in less risk-low return scenario. On the other front, bank size ensures to gain advantage from economies of scale that positively impacts performance of providing the benefit of low costs operation (Agu,1992). The study results from ROE model supports the later argument where banks' profitability is positively improved by operating at optimum economics of scale. This is consistent with our previous finding on the significant impact of optimum scale of operation on performances and a variable explaining the variation in efficiency among banks operating in the Ethiopian banking industry. In addition, the result also shows that big banks have maintained a reasonable level of capital in line with their profitability trends. As shown in previous sections, capital level determination for big banks is an internal decision, whereas, the regulatory set the required capital level for medium and small banks. The study's output in relation to the RoA and NIM model, however, is negative. The argument in such regard as well is consistent with our previous findings (on impact of ownership) in that large banks could be profitable by reducing their prices. Therefore, optimum scale of operation provides the flexibility for banks to operate in lower net interest margin set-up that turns into market share growth if potentially exploited by the big banks. Nevertheless, the study result on the impact of market concentration on prices shows that big banks are not engaged in collusive behavior to affect the prices in the market. This has provided a benefit to small banks to record a healthier profitability performance by flexibly adjusting prices and without facing a counter response by big banks.

The impact of building a low cost deposit structure through increasing the share of demand deposits in the deposit mix, (DDTD), is positively related to performances in all models. Therefore, the increase in the ratio of demand deposit to total deposit increases the profitability of commercial banks. The result suggests that better performance is not only associated with the size in deposit (market growth as explained above) but also has established an association with banks' conscious decision to direct their resource mobilization towards cost saving deposit types. Therefore, banks ensure increasing profitability record by increasing the share of demand deposits which is a cheaper source of funds. The study result, however, is not statistically significant in case the profitability models. The insignificant relationship in profit models is a result of increase in other deposit types 
(saving and fixed time) that could reduce the share of demand deposits. In addition, demand deposits by nature are volatile to be withdrawn on demand, therefore, a growth in the share of such deposit types affects the motive to set up a stable deposit structure that can support the lending businesses. Therefore, credit extension decisions are much a result of other stable sources of fund than demand deposits. The price model, however, has a statistically significant relation with the share of demand deposit on total deposits. The relationship is expected as the cost saving advantage from the cheaper deposit type has a downward effect on the effective cost of fund of the entire deposit stock. This potentially reduces the interest expense of banks and widens the net interest margin.

\section{Robustness Test (Specification Tests after the Result)}

The residual statistics shows that the error term has a normal distribution with a mean of 0 . Hence, the normality assumption holds. The results from the VIF table suggest that VIF is not greater than 10 for any of the explanatory variables. The Breusch-Pagan / Cook-Weisberg test for heteroskedasticity test shows that at 5\% level of significance, the p-value is higher showing that heteroskedasticy is not significant in the model. The small value of ch-square also supports the constant variance of the error term. The result has shown that the Dstatistic (2.232) appear closer to 2 depicting negative correlation. As suggested by Field (2009), values less than 1 or greater than 3 are a cause of concern. Hence, from Field's rule of thumb it can be inferred that autocorrelation is not serious.

\section{Summary and Conclusions}

The study has investigated one of the key research questions: how do external factors relate to bank performance? It has set a panel regression model that comprised explanatory variables from the macroeconomic and the banking sector. It has run a regression model based on three dependent performance measures, two of which were related to profit and the rest was a price model. The selected variables have established a relationship with performance in most of the models. The result witnessed the fact that bank performance is determined by factors beyond the management control. These include the macroeconomic situations like economic growth and trade. In addition, sector related variables such as the rate of market growth and access to cost saving deposits have impact on banks performances. Therefore, related to the research question, RQ: 'How do external (sector and macroeconomic) factors relate to bank performance?', it was explored that some of the identified proxy variables are statistically significantly related to performances. Therefore, the result rejects the null hypothesis that external factors (sector and macroeconomic) have no impact on bank performances. As a variable representing macroeconomic factors, the economic growth rate (RGDP) on bank performance is positive and significant in the profit models. Nevertheless, the relationship on the price measure (NIM) is negative and insignificant. On the other font, the impact of trade deficit on performances shows that being a net importing country has a negative and significant impact on both profitability (RoA and RoE) and price (NIM) measures. The result, therefore, points that the widening trade deficit should be one of the determinant macroeconomic variables to be considered by the government in its policy framework to improve bank performances. Most importantly, economies with enormous trade deficit that derived from the double edge impact of a rise in import demand and deteriorating export performances could potentially impact their banking performances. The sluggish growth in earnings from export affects the capacity to mobilize both local and foreign currency denominated resources from the market. The effect of such trend remained significant because of its strong effect on both channels of the banks income sources. On the one side, less export earning affects the intermediation business through limiting the opportunity to raise abundant local deposits. On the other front, it affects the earning from international banking activities by channeling lower amount of foreign currency to the banking system. Most importantly, the limited export earning leads to unfair competition and behavior to reign in the system.

With regard to inflation, the quantitative study finds that the annual rate of inflation has established a positive but statistically insignificant relationship with performances. This is a surprising result as it suggests that banks' performance get improved during increased inflation. A strong argument raised relates that banks are not adjusting their interest rate in line with the move in the inflation rate. Therefore, both savers and borrowers are entertained with a nominal interest rate. In such process, the borrowers are benefited from a reduced real interest while depositors are earning the output of a negative real interest rate. This, however, is mitigated by the depositors' intention to deposit their saving at banks with the purpose of safety of funds. Banks as well are compensating their loss from inflation by lending cutting back their real interest payment to the depositors. Such practice seems to negatively impact the depositors rather than the banks. But its level of impact on depositors is not known. The study, therefore, finds that the impact of inflation on bank performance is uncertain and the impact of a real negative interest rate on the depositors as a further research area. Some scholars say that the relationship between inflation and banks performance is debatable (Athanasoglo, 2005), the direction of relationship is unclear (Vong and Chan 2009) or the effect depends on whether inflation is anticipated or unanticipated (Perry 1992). The sector related variable market growth rate (MKGD) has a statistically positive and significant relationship with the profitability measures (RoA and RoE. But, it is negatively associated with 
the price model (NIM). The result is as expected following the argument that an expanding market provides an opportunity to mobilize resources at ease. Therefore, the intermediation business reinforced as a result of the strength in the supply side. With a parallel growth in the demand side (credit), the intermediation activity of banks will be strong to yield in notable profitability performances. Nevertheless, the study finds that the growth in market is negatively associated with the price model (NIM). This remains in line with our argument above, where, in times of heated intermediation associated to high demand for credits and excess supply for deposits, the lending interest rate will be in pressure. The impact of building a low cost deposit structure through increasing the share of demand deposits in the deposit mix, (DDTD), is positively related with performances in all models. Therefore, it is found that the increase in the ratio of demand deposit to total deposit increases the profitability of commercial banks. The study finds that cost saving from high share of low cost deposits will benefit performances by reducing the banks' cost. Nevertheless, its impact might be insignificant as demand deposits are not a stable fund to be wholly utilized for lending purposes. In addition, the benefit from cost saving deposits might be lost unless there is a robust control on other expense components. Its effect can also be reduced if it indulges banks management in low risk taking endeavor as the low cost push management towards keeping excess liquidity as cost of holding liquidity is low and its trade-off with profitability is not significant.

\section{Policy Direction}

Policy makers should aim to align the banking sector performance to the functioning of the economy so that banks' operation will be closely controlled with the changes in the economy. Ensuring market determined prices, exchange rates, inflation adjusted performances etc. should deserve attention so that banking operations will be guided by the economy policy and models of the government. In addition, policy directions should enhance the contribution of the banking and the financial sector in the economy. In such regard, narrowing the trade deficit through export enhancing and import substitution strategies deserve the policy makers' attention. This should be supported by a market driven exchange regime and pricing system.

\section{References}

Agu, C. (1992). Analysis of the Determinants of the Nigerian Banking Systems' Profits and Profitability Performance. Savings and Development, pp. 353 - 369.

Athanasoglou, P., Delis, M. and Staikouras, C. (2005). Determinants of bank profitability in the South Eastern European region, Journal of Financial Decision Making, Vol. 2, pp. 1-17.

Berger, A. (1995). The profit-structure relationship in banking, Tests of market- power and efficient-structure hypotheses. Journal of Money, Credit and Banking, 27(2), 404-431.

Berger, A. and Humphrey, D. (1997). Bank scale economies, mergers, concentration, and efficiency: The US experience. Working Paper 94-25, Financial Institutions Centre, The Wharton School, University of Pennsylvania.

Bikker,J. and K. Haaf, K. (2002). Competition, Concentration and Their Relationship: An Empirical Analysis of the Banking Industry, Journal of Banking and Finance, 26, pp. 2191-2214.

Borio, C, C Furfine and P Lowe (2001): "Procyclicality of the financial system and financial stability: Issues and policy options" in "Marrying the macro- and micro-prudential dimensions of financial stability", BIS Papers, no 1, March, pp 1-57.

Bourke, P. (1989). Concentration and Other Determinants of Bank Profitability in Europe, North America and Australia, Journal of Banking and Finance, Vol. 13, pp. 65-79.

Chantapong, S. (2005). Comparative study of domestic and foreign bank performance in Thailand: the regression analysis, Economic Change and Restructuring, Vol. 38, pp. 63-83.

Chirwa, E. (2001). Market Structure, Liberalization and Performance in the Malawian Banking Industry, AERC Research Paper 108, Nairobi, African Economic Research Consortium.

Civelek, M. and Al-Alami, M. (1991). An Empirical investigation of the Concentration-Profitability Relationship in the Jordanian Banking System, Savings and Development, 15, pp. $247-59$.

Geda, A. (2006). The Structure and Performance of Ethiopia's Financial Sector in the Pre- and Post-Reform Period with a Special Focus on Banking UNU-WIDER, Research Paper No. 2006/112, united nations university.

Goddard, J., Molyneux, P., Wilson, J. and Tavakoli, M. (2004). European banking: an overview. Journal of Banking and Finance, 31 (7), pp.1911-35.

IMF, 2007, World Economic and Financial Surveys REO Regional Economic Outlook Sub-Saharan Africa: online resource, https://www.imf.org/external/pubs/ft/reo/2007/AFR/ENG/sreo0407.pdf accessed on January,2017.

Levine, R. ( 2005). Finance and Growth, Theory and Evidence, Handbook of Economic Growth, Volume 1, Part A, 2005, pp. 865-934.

McKinnon, R.(1973). Money and Capital in Economic Development. Washington, D.C.: Brookings Institution. 
MOFED, , Ministry of Finance and Economic Development, Macro-economic report of various period.

National Bank of Ethiopia Annual, report of various times accessed at www.nbe.gov.et

National Bank of Ethiopia various Directives accessed at www. nbe.gov.et

NBE Circular MFAD/205/15

Olweny, T., Shipho, T.M. (2011) Effects of Banking Sectoral Factors on the Profitability of Commercial Banks in Kenya. Economics and Finance Review, 1(5), 1-30.

Ongore, V. (2011). Determinants of financial performance of commercial banks in Kenya. International Journal of Economics and Financial Issues, 3(1), pp.237-252.

Perry, P. (1992). Do banks gain or lose from inflation?, Journal of Retail Banking, Vol. 14 No. 2, pp. 25-30.

Rhoades, S. and Rutz,R. (1982). Market Power and Firm Risk, A Test of the Quiet-Life Hypothesis, Journal of Monetary Economics 9,pp.73-85.

Shaw, S. (1973). Financial Deepening in Economic Development. New York,Oxford University Press.

Smirlock, M. (1985). Evidence on the (Non) Relationship Between Concentration and Profitability in Banking, Journal of Money, Credit and Banking, Vol. 17, $\mathrm{N}^{\circ} 1$, pp.69-83.

Vong, P., and Chan, H. (2009). Determinants of bank profitability in Macao. Macau Monetary Research Bulletin,pp.93-113. 